\title{
Modern Suriye Tiyatrosunda Ahmed Ebû Halîl el-Kabbânî
}

\author{
DOI: 10.26466/opus.819011
}

*

\section{Turgay Gökgöz *}

* Dr. Öğr. Üyesi, Kilis 7 Aralık Üniversitesi, Fen-Edebiyat Fakültesi, Kilis / Türkiye

E-Posta: turgaygokgoz@kilis.edu.tr

ORCID: $\underline{0000-0002-3436-6583}$

\section{Öz}

Napolyon'un 1798 yılında Mısır'ı işgali ile modern edebiyatta gelişmeler meydana gelmiş, edebi ve kültürel faaliyetler başta olmak üzere çeşitli alanlarda ilerlemeler kaydedilmeye başlanmıştır. İlk modern Arap tiyatrosu Lübnan'da başlasa da koşulların ve imkanların iyi olması ve en değerli müzisyenlerin Mısır'da yer alması nedeniyle tiyatro sanatı daha çok Mısır'da yoğunlaşmıştır. Mısırlı tiyatro topluluklar XIX. yüzyılda diğer Arap ülkelerinde gezilere başlamışlardır. Bu bağlamda tiyatro sanatı önce Mısır'da akabinde Lübnan'da ve sonra da diğer Arap ülkelerinde gelişmeye başladığı söylenebilir. Bu gelişmelerin yanı sıra Lübnan'da tiyatro sahasında Mârûn Nakkâş̧ön plana çıkarken 1847 yılında ilk tiyatro oyununu sahnelemiştir. Suriye'de ise ilk tiyatro oyunu Makedonyalı İskender adl romanının müellifi olan Lübnanlı İbrâhîm el-Ahdeb'in Vali Raşid Paşa'nın teklifiyle eserini tiyatroya uyarlaması ve sahnelemesi ile ortaya çıkmıştır. İlgili oyun halk nezdinde oldukça ilgi görmüştür. Bunun yanı sıra

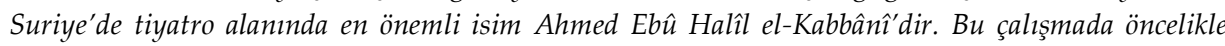

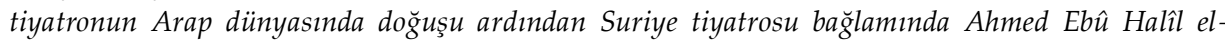
Kabbânî ele alınacaktır.

Anahtar Kelimeler: $\quad$ Ahmed Ebûu Halîl el-Kabbânî, Suriye Tiyatrosu, Arap Edebiyatı. 


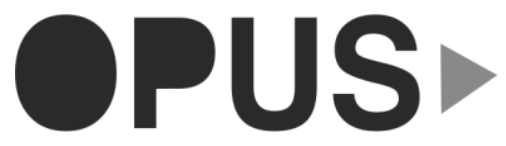

Uluslararası Toplum Araştırmaları Dergisi International Journal of Society Researches
E-ISSN : 2528-9535

Yıl Year : 10

Cilt Volume: 16

Sayı Issue :Eğitim ve Toplum Özel Sayısı

Aralık December 2020

Makalenin Kabul Tarihi Accepted Date: 31/12/2020

\title{
Ahmad Abû Halîl Al-Qabbânî in the Modern Syrian Theater
}

\begin{abstract}
With the occupation of Egypt in 1798 by Napoleon, developments in modern literature took place, and progress was made in various fields, especially in literary and cultural activities. Although the first modern Arab theater started in Lebanon, it was concentrated in Egypt due to the good conditions and opportunities and the most valuable musicians in Egypt. In the 19th century, Egyptian theater companies began to travel to other Arab countries. In this context, it can be said that theater art started to develop first in Egypt, then in Lebanon and other Arab countries. In addition to these developments, Mârûn Nakkash came to the fore in the theater field in Lebanon, and staged her first theater play in 1847. In Syria, first theater play occured with the adaptation of the novel called Macedonian Alexander which was written by Lebanese Ibrâhim al-Ahdeb and it was staged with the proposal of Governor

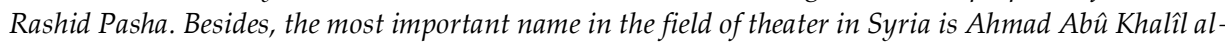
Qabbânî. In this study, first of all, the birth of the theater in the Arab world, and then in the context of the Syrian theater, Ahmad Abu Khalîl al-Kabbânî will be discussed.
\end{abstract}

Keywords: Ahmad Abû Khalîl al-Qabbânî, Syrian Theater, Arabic Literature 


\section{Giriş}

Modern Arap tiyatrosunun doğuşu 1847 yılında Osmanlı toprakları dâhilinde yer alan Lübnan'da meydana gelmiştir. Fakat en iyi yazarların ve aktörlerin daha iyi koşullar arayışında olmaları hasebiyle tiyatro sanatının Mısır'da yoğunlaştığı görülür. Tiyatrolarda müziğin önemli bir yeri oldugŭ için en değerli müzisyenler buralarda çalışmaktaydı. Amatör aktörler bir topluluktan diğerine özgürce geçerken aktristler ise sahneye çkabilmeye başlamışlard1. Ancak aktristler genellikle Yahudi ve Hristiyan kadınlardan ibaretti. Bazı güçlü ailelerden gelen Müslüman kadınların ise I. Dünya Savaşı'na dek kadınların özgürleşmesi adına sahneye çıktıkları görülmektedir (Osnes, t.y., s.16).

Arap bilim insanları, Batı tarzındaki ilk modern Arapça eserin Mârûn enNakkâş'ın 1847 senesinde Beyrut'ta sahnelenen el-Bahil (Cimri) adlı oyunu olduğu hususunda hemfikirlerdir. Ancak Arapça olarak yayımlanmış ilk modern oyunun Abraham Daninos'a ait olan Nuzhatu'l-Muştâk ve Ğussati'l'Uş̧̧âk fi'Medîneti Tiryâki'l-'Irâk adlı oyunun 1847 yılında Cezayir'de anonim olarak yayımlandığı hususu 1990'lı yılların başlarında Manchester Üniversitesi'nden Dr. Philip Sadgrove tarafından keşfedilerek, 1996 yılında Dr. Shmuel Moreh ile birlikte açıklanmıştır. Bu nedenle bugün hâlâ sahnelenen ilk oyunun hangisi olduğu sorusuna cevap aranmakta ve tartışılmaya devam edilmektedir (Amine, Carlson, 2012, s.71).

Mısır'da tiyatro toplulukları, XIX. yüzyılda diğer Arap ülkelerine yönelik geziler yapmaya başladılar. Bu geziler ilgili ülkelerdeki Arap tiyatrosunu ciddi bir şekilde etkiledi. Bölgedeki Avrupa etkisinin sınırlı oluşu ve güçlü İslami duyguların varlı̆̆ı sebebiyle Arap Yarımadasında tiyatro sanatı hemen hemen hiç görülmedi. Arap tiyatrosunun gelişmeye devam edebileceğine dair iyimser bir atmosfer bulunsa da merkezi hükümetlerin varlığı ve İslami tepkiler nedeniyle bu hareketin bir düşüş yaşayabileceği korkusu da her zaman mevcuttu (Osnes, t.y., s.16-17).

Mısır'da ise tiyatro sanatına bakıldığında 1884 yılından I. Dünya Savaşına kadarki yıllar ilk dönem Mısır tiyatrosunun gerçekten en canlı olduğu senelerdi. Nitekim 1880'lerde Mısır; Lübnan ve Suriye' den çeşitli tiyatro gruplarının akınına sahne olmuştur. Bu gruplar, daha çok seyirci kitlesi toplayabilmek amacıyla birbirleriyle yarış halinde olmuşlardır. Önemli bir durumu 
ifade etmek gerekir ki bu gruplar tiyatro sanatını yüksek bir seviyeye taşımaktan ziyade, halkın zevkine göre hitap edebilmek adına rekabet halindeydiler. Gaye, salt olarak halka hoş vakit geçirtmek ve kendi geçimlerini sağlamaktı. Bu nedenle de musiki ve şarkı, tiyatrolarda yer alan temel unsurlar arasındaydı. Ayrıca, yabancı dillerden gerçekleştirilen çevirilerin eksikliklerini gidermek için senaryoya şiirler, musiki ve raks ilave edilmekteydi. Halkın bu minvaldeki taleplerine en iyi cevap verebilen isim ise Ahmed Ebû Halîl el-Kabbânî idi. Suriye'deki Arap tiyatrosunun öncüsü olarak görülen elKabbânî, oyunlarını şarkı, musiki ve raksla harmanlamıştır (Er, 1990, s.136).

\section{Ahmed Ebû Halîl el-Kabbânî'nin Hayatı}

Ahmed Ebû Halîl el-Kabbânî (1833-1903), Suriye'de tiyatro sanatının en önde gelen isimlerinden birisi olarak kabul edilir. XIX. yüzyıl Arap tiyatro sanat1nın öncü isimleri arasında yer alan, tiyatro sanatının gelişmesinde, telif edilmesi ve temsilinde ve de müzikal hale gelişinde oldukça büyük katkıları olan Ahmed Ebû Halîl el-Kabbânî, Konya'dan Şam'a göç etmiş olan Türk kökenli bir ailenin bir üyesi olarak 1833 yılında Şam'da dünyaya gelir. Asıl soy isimleri Akbıyık'tır. Kendisi, ailesinin Bâbu'l-Câbiyye mahallesinde kantar işiyle uğraşması neticesinde "kabbân" kelimesine nispetle el-Kabbânî adıyla ün kazanır. Kendisi, önce bir Kur'an okulunda, sonra camilerde ve ardından önde gelen âlim ve yazarlarla çalışmıştır. Küçük yaşlardan itibaren dini eğitim alan el-Kabbânî, hocalık icazeti alıncaya değin bu tahsilini sürdürmüştür. Ayrıca kendisindeki musiki ve gösteri yeteneği henüz on iki yaşında gün yüzüne çıkmış olup artarak da devam etmiştir. Keza bu dönemde et-Tâvûsiyye Üniversitesi hocalarından birinden Türkçe öğrendikten sonra 18 yaşına gelince Farsçayı iyi bir şekilde öğrenerek dikkatleri üzerine çekmeye başlamıştır. Geleneksel İslami eğitime haiz olan el-Kabbânî, hiçbir Batı dilini bilmemekteydi. Gençliğinden itibaren zeceller nazmederdi, muvaşşahalar ve şarkılar söylerdi ki bu konu da dikkatleri üzerine çekmeyi başardı. Öğretmeni ve arkadaşı Şeyh Ahmed ‘Ukayl el-Halebî'nin rehberliğinde müzik ve "semah" adı verilen Endülüs kökenli popüler bir yerel dans formunu çalıştı. Semah dansını ve gölge oyununu takdim eden Seyyid Ali Habîb'den etkilendi. Doğuştan gelen temsili ve musiki kabiliyeti mevcuttu. O tiyatroya ne Mârûn Nakkâş'ın eserlerinde ve ne de Lübnanlıların Misır' daki kumpanyalarında bulunan ğınâ ve raks gibi Batılıların operet tipindeki yeni unsurlarını kazandırmışır (el- 
Fâhûrî, 1986, s.112-113; el-Haffâr, 2006, s.205; ez-Ziriklî,1992, s.127-128, elCundî, 1954, s.249; Sadgrove, 2010, s.266-267; Savran, 1991, s.66; İshakoğlu, 2010, s.191-192).

el-Kabbânî'nin tiyatroya başlaması 1860'lı yılların sonlarına doğru gerçekleşir. Kendisinin kantarcıllktan bu sanata geçişi, musikiye ve şarkıya yönelik ilgisinden ve bu sahadaki yeteneğinden ileri gelir. Bilindiği gibi Lübnan'da başlayan ilk Arap tiyatrosu daha çok operet halindeydi. el-Kabbânî de enNakkâş'ın bu türden oyunlarını duymuş ve Lübnanlıların Şam'da oynadığı temsilleri izleyerek bu alana atılmıştır (Er, 1990, 137).

1860 yılında Seyyid Suleymân Sâfínnin Humus'ta oyunlar oynadığı söylenir. Lübnanlı oyun yazarı İbrâhîm el-Ahdeb, Vali Raşid Paşa'nın oğullarının sünnet töreninde Racine'nin Alexandre le Grand adlı oyununu İskender elMakdûnî adıyla uyarlayarak sergilemek için 1868 yılında bir topluluğu Şam'a götürdü. el-Kabbânî de bu oyunu izleme firsatı yakalamıştı (el-Haffâr, 2006, s.205; Sadgrove, 2010, s.267).

el-Kabbânî; Mârûn ve Selîm el-Nakkâş'ın eserleriyle birlikte, Arap ve İslam mirasından ve halk hikâyelerinden türetilen çok sevdiği şarkı, müzik ve dansları içeren kendi oyunlarını üretti. İlk önce bir miktar başarı elde etti, hatta yetkililer tarafından özellikle de İskender Farah'ı Şam'da elKabbânî'nin önemli bir üyesi olacağı bir tiyatro topluluğu kurması için görevlendiren Türk valisi Mithat Paşa tarafından cesaretlendirildi. Bununla birlikte bir süre sonra el-Kabbânî, tiyatrosunu kapatmaya ve faaliyetlerini sona erdirmeye zorlayan mutaassıp hocaların tepkilerine maruz kaldı. el-Kabbânî, 1884 yılında grubunu İskenderiye'ye taşıdı ve buradaki Zîzîniyâ tiyatrosunda ve ed-Denûb kahvesinde oyunlarını oynamaya başladı. Kısa süre sonra Kahire'de, Opera Binası'nda ve daha sonra Mısır'ın taşra kentlerinde bile oyunculuk yapabildi (https://shodhganga.inflibnet.ac.in/bitstream/10603/104470/10/10 chapter\%202.pdf 05.10.2020; Badawi, 1988, s.57;).

el-Kabbânî ve grubu, henüz el-Minyâ' da iken Kahire'deki tiyatro binalarının yandığı haberi duyulur. Bu nedenle de Kahire'ye dönerler. Ancak söz konusu talihsiz olay grubun dağılmasına neden olur ve el-Kabbânî Mrsır'daki tiyatro serüvenini bitirerek vatanı Suriye'ye döner. Oldukça fakirleşir. Artık el-Kabbânî çökmüş ve inzivaya çekilmiştir. Bir süre sonra Bâb-1 Âli kâtipleri reisi Ahmed 'İzzed el-'Âbid Paşa'nın girişimleri sonucunda İstanbul'da Sultan'ın huzuruna çıartılan el-Kabbânî'ye hazineden ailesine yetecek kadar maaş verilir. Ama kendisi bunu teşekkür ederek reddeder. el- 
Kabbânî geçen birkaç yılın ardından 21 Aralık 1903 tarihinde kolera hastalığından Şam'da hayata veda eder. (el-Cundî, 1954, s.251; Er,1990, s.139-140; Savran, 1991, s.66).

\section{Ahmed Ebû Halîl el-Kabbânî'nin Tiyatroculuğu}

el-Kabbânî'nin gösteri sanatlarına olan ilgisi geleneksel oyunların etkisiyle gerçekleşmiştir. Bu hususta tiyatro sanatçısı Vasfî el-Mâlih'e göre, el-Kabbânî önceleri Ali Habîb isimli gölge oyunu sanatçısından oldukça etkilenmiş ve tek başına kaldığında onu taklit eder olmuştur. Zamanla geleneksel oyunlardan ziyade insanların aktif olarak yer aldığı oyunlara ilgi duymuştur. "Bu bağlamda arkadaşlarma "Birimiz bir oyun yazsa da beş arkadaş bunu sergilesek daha doğal olmaz mı?" diyerek sorular yöneltmiştir. Nitekim el-Kabbânî’de filizlenen tiyatro sevgisi ilerleyen yıllarda kendisinin ayrılmaz bir parçası haline gelecektir (İshakoğlu, 2010,s.192).

Aslında el-Kabbânî'nin tiyatro sahasındaki başarısını döneminin Şam valilerine borçlu olduğunu belirtmek yerinde olacaktır. el-Kabbânî'nin bir oyununu kendi onuruna düzenlenen bir törende izleme firsatı yakalayan Şam valisi Abdullatif Subhî Paşa (1871 - 1872), bu temsili beğenerek el-Kabbânî'yi bu yolda devam etmesi için teşvik etmiştir. Böylece el-Kabbânî, yeniliklere karşı bir yapıya sahip olan Şam halkının karşısına çıkma cesaretini kendisinde bulmuştur (Er, 1990, s.137).

Vali Subhî Paşa (1872-1873)'nın görevi esnasında el-Kabbânî'nin Tûmâ Kapısı'ndaki bir Lazarist okulunda Moliere'nin klasiği olan L'Avare'nin bir Fransız tiyatro topluluğu tarafından sahnelenen performansı izleyerek ilk tiyatro hazzını aldığı söylenir. Bu sanatla ilgilendiği ilk zamanlarda elKabbânî, tiyatroya hobi olarak bakmaktadır. Bazen arkadaşlarının bazen ise akrabalarının evlerinde gerçekleşen gece muhabbetlerinde sergilediği oyunlarla ortaya çıkan yeteneği, kendisinin ilk tiyatro eseri olan Nâkiru'l-Cemîl (Nankör) ile başka bir boyuta evrilmiştir. Oyun, hasta bir genci iyileştiren ve onu yakın arkadaşı yapan iyi huylu genç Halim'in hikâyesini anlatır. Kâdir, patronunu öldürmeye çalışırken yanlışlıkla Veliaht Prensi öldürür ve ardından Halim'i cinayetle suçlar ve sonrasında ölüm cezasına çarptırılır. Ancak gerçek katil Kâdir'in kimliği ortaya çıkar. Halim, kral tarafından affedilir ve kralın kızıyla evlenir. Bu oyunun yazarlığı tartışmaya açık olup iki versiyonu mevcuttur: Birisi el-Kabbânî tarafından diğeri ise Antûn Şihaybar tarafından 
1879 yılında yazılmıştır. Her ikisi de hem yapı hem de ifade açısından yakından ilişkilidir. Profesör Muhammed Yûsuf Necm, el-Kabbânî'nin kendi versiyonunun diyaloğunu oyuna dayalı bir romandan yola çıkarak yeniden tasarlamıştır (Sadgrove, 2010, s.267).

el-Kabbânî, söz konusu bu eserin ardından üç günde kaleme aldığı Vaddâh (Parlak) operetinde rolleri arkadaşlarına dağıtmış, önce birinin evinde oyunun provasını yapmışlar, ardından da Bâbu'l-Câbiyye mahallesinde "et-Tilyân" gazinosunda halkın karşısında oynamışlardır. Bu oyun seyircilerden beklenildiğinden daha fazla ilgi görmüştür (el-Cundî, 1954, s.249; el-Haffâr, 2006, s.206; Er, 1990, 137). el-Kabbânî'nin içinden geçtiği bu dönem on y1l sürerken kendisinin kaleme aldığı ve bestekarlığını yaptığı müzikal tiyatro eserleri Şam gecelerini süslemiştir. el-Kabbânî sergilediği bu oyunlarda kadın rollerinde toplumsal şartlardan ötürü erkeklere rol vermesi kendisini rahatsız eden bir durum olmuştur (İshakoğlu, 2010,s.193).

1872 yılında Subhî Paşa başka bir yere görevlendirildiğinde gerek onun yerine gelen Mehmed Halet Paşa (1872-1875) ve gerekse sonraki valiler Esad Paşa (1875), Ahmed Hamdî Paşa (1875-1876 / 1879-1884), Râşid Nâşit Paşa (1876), Ziya Paşa (1876-1877), Ömer Fevzî Paşa (1877-1878), Ahmet Cevdet Paşa (1878) ve Mithad Paşa (1878-1879)'dan aynı desteği görmeye devam etmiştir. Özellikle Mithat Paşa, manevi desteğinin yanında maddi yardımlar da yapmıştır (Er, 1990, s.137-138).

el-Kabbânı̂'nin tiyatroculuğunun bir diğer aşamasına bakıldığında acemilikten siyrilıp profesyonelliğe geçişin olduğu görülür. Bu dönem ise Mithat Paşa'nın valiliğine denk gelir. Vali, atandıktan sonra geleneksel tiyatronun varlığının devam ettiğini gördügünde modern tiyatro sanatını icra edebilecek kişileri araştırmaya koyulur. Vali, el-Kabbânî ve ekibini duyunca onlardan bir oyun tertip etmesini istemiştir. el-Kabbânî ise masraflar karşıllğında valinin teklifini kabul etmiştir. Hazırlıklara başlanmış Vali, el-Kabbânî'nin kendisinin kaleme aldığı el-Emîr Mahmûd Neclu Şâhî'l-Acem adlı temsilinde gerekli olan kostümlerin ve diğer malzemelerin temini için el-Kabbânîye Şam belediyesinden dokuz yüz altın lira verilmesi emrinde bulunmuştur. Bunun yanı sıra hem gümrük memurluğu yapan hem de tiyatroya meraklı bir isim olan İskender Farah'a, el-Kabbânî'ye yardımcı olması için vali tarafından izin verilmiştir. el-Kabbânî, İskender Farah ile birlikte büyük bir ekip kurmuş ve Lübnan'dan getirtilen Lebîbe ve Meryem adlarında iki kadınla, Mûsâ Ebû elHabî isimli bir Hristiyan diğer ikisi de Râğıb Semsemiyye ve Tevfîk Şems adlı 
iki Müslüman oyuncular arasında rolleri paylaştırmıştır. Hayallerini gerçekleştirme şansı yakalayan el-Kabbânî, Tûmâ Kapısı'ndaki Cuneyne el-Efendî bahçesinde büyük bir yer kiralamış ve İpek Çarşısı ile Bâbu'l-Berîd arasındaki Gümrük Kervansarayı'nda performanslarını sergilemişlerdir. Performansları arasında, Misır Hidivi tarafindan yaptırılan Verdi operasının librettosunun Camille de Laclos tarafından yapılan Fransızca çevirisinden el-Kabbânî tarafından uyarlanmış olan Aida vardı. Bu eser, Radames ile köle kız Aida arasındaki aşk iliş̧isinin eski Mısır'dan trajik bir hikâyesini anlatır. el-Kabbânî'nin sergilediği oyunlar vali ile seyircilerin beğenisine haiz olurken bazı mutaassıp hocaların da tepkisine neden olmuştur (el-Cundî, 1954, s.249; el-Haffâr, 2006, s.206; Sadgrove, 2010, s.268; İshakoğlu, 2010, 193; Er, 1990, s.137).

el-Kabbânî bir süre sonra İskender Farah'la beraber yine Mithad Paşa'nın direktifleriyle, 1870'li yıllarda Selîm Halîl en-Nakkâş tarafından İtalyancadan çevrilen Aida operasını tekrar sahnelemiş ve halkın teveccühü üzerine defalarca oynanmıştır. Valinin istekleri doğrultusunda farklı oyunlar sahnelemek isteyen el-Kabbânî ve İskender Farah, nihayetinde Mârûn en-Nakkâş'in Ebu'l-Hasen el-Muğaffel ev Hârûn er-Reşîd adlı komedisini oynamayı kararlaştırırlar. Hârûn er-Reşîl'in Ebu'l-Hasen el-Muğaffel tiplemesinde görünmesine büyük tepki gösteren din adamları, Mithad Paşa'nın himayesindeki elKabbânî'ye karşı Suriye'de ellerinden bir şey gelmeyince, meseleyi Bâb-1 Âlî̀ye götürürler. Bu kişilerden Şeyh Sa'îd el-Ğabrâ' adlı biri, Sultan II. Abdülhamid'in Cuma namazına gelişini firsat bilerek camide Suriye'deki gelişmeleri Sultan'a şikâyet eder ve şu ifadeleri kullanır: "Yetiş imdadımıza ey Mü'minlerin Emîri! Dinsizlik ve ahlaksizlık Şam'da kol geziyor. Namuslar elden gitti. Şeref kalmadı. Kadın erkek karmakarışık oldu". Bunun üzerine Sultan II. Abdülhamid, bir ferman göndererek el-Kabbânî'nin tiyatrosunu kapattırır ve faaliyetlerini yasaklatır. (Haffâr, 2006, s.206; Er, 1990, s.138).

Yaşanan bu gelişmelerin ardından el-Kabbânî bir süre Humus'ta hayatına devam etmiştir. el-Kabbânî, İskenderiye'deki zengin bir Suriyeli tüccar olan arkadaşı Sa'dullah Hallâbû'ya bir mektup yazdı. Kendisi, el-Kabbânî'ye 1870 yılından beri modern Arap tiyatrosu geleneğinin ve köklü Fransız ve İtalyan tiyatrolarının olduğu Mısır'da şansını denemesini tavsiye etti. Sa'dullah Hallâbû'nun teşvikiyle aktörler, yazarlar, şairler, besteciler, şarkıcılar, müzisyenler ve semah dansçılarından oluşan elli kişilik bir grupla birlikte yeni bir sayfa açarak 1884 yılında İskenderiye'ye gelen el-Kabbânî, gelişinden birkaç 
gün sonra Zîzîniyâ tiyatrosunda ve ed-Denûbu'l-Ezrak adlı kahvede oyunlarına başlar. İskenderiye'de otuz beş oyun sergileyen el-Kabbânî'nin burada kendi telifi olan oyunları şu şekildedir: Nefhu'r-Rabbî, Nâkiru'l-Cemîl, el-Emîr Mahmûd, 'Ifffetu'l-Muhibbîn ev Vellâde, eş-Şeyh Vaddâh ve Misbâh ve Kûtu'l-Ervâh. Her oyun genellikle dans içerir ve ardından Muhiddîn ed-Dimeşkî veya komedyen Ebu'l-Hayr en-Naccâr tarafından sunulan bir pandomim, tek perdelik bir fars veya k1liç kalkan oyunu izlerdi (Sadgrove, 2010, 268; Haffâr, 2006, 206). Nitekim el-Kabbânî'nin İskenderiye'ye gelişine 23 Temmuz 1881 tarihli el-Ahrâm gazetesinin 1974 nolu sayısında yer verilmişti (el-Cundî, 1954, s.250; Haffâr, 2006, s.206).

el-Kabbânî́nin gösterime koyduğu oyunların çoğu, kendi telifi olan ve aynı zamanda da eğlendirmeyi hedefleyen Binbir Gece Masalları ve Arap halk hikâyeleri türünden eserlerdir. Bu eserler, şarkı, dans ve müziği de bir araya getirmekteydi. Bu yönüyle el-Kabbânî, Misır'da müzikal tiyatronun tohumların eken ve operet türünü ilk sahneleyen kişi olarak görülür. Hem enstrüman çalmada, hem şarkı söylemede, hem de beste yapımında yetenekli olan el-Kabbânî, sonraları Mısır'da müzikal tiyatro ile meşgul olacak olan eşŞeyh Selâme Hicâzî, Seyyid Derviş ve diğerlerine öncü bir isim olmuştur (Er, 1990, s.138-139).

el-Kabbânî yenilikçiden ziyade geleneksel bir yapıya haizdi. Bununla birlikte Mârûn el-Nakkâş̧' in geleneksel setiyle mükemmel bir uyum içindeydi. Kendisi, Misır'da tiyatroyu etkileyen "Arap operetinin" yaratıcısı olarak düşünülebilir. Müzikal dramanın sadece Misır'da değil, tüm Arap dünyasında yaygınlaşmasına yardımcı oldu. Dahası, daha geleneksel, sahip olduğu kültürel hayatı, geçmişi ve Arap diline daha fazla hâkim olması nedeniyle Arap Geceleri de dâhil olmak üzere Arapların kültürel ve edebi mirasını bir kaynak olarak görme geleneğinin oluşturulmasında önemli bir rol oynadı ve bu şekilde de Arap oyun yazarları için ilham kaynağı haline geldi (https://shodhganga.inflibnet.ac.in/bitstream/10603/104470/10/10 chapter\%202.pdf 05.10.2020).

el-Kabbânî tarafından 1884 ile 1900 yılları arasında 150 performans sergilenirken, 1884 yılında gerçekleşen söz konusu Mısır seyahati ile ilk önce İskenderiye şehrine yerleşip burada otuz beş oyun oynamıştır. Nitekim gösterilerde Mısır halkının aşina olmadığı sema gösterileri de sunulmuştur. Bazı oyunlar, el-Kabbânî'nin ve Mısır sahnesine hâkim diğer önde gelen Suriyeli toplulukların repertuarının bir parçası olmuştur. 
1884 yılında Hidiv Tevfík Paşa'nın davetlisi olarak Kahire yolunu tutan el-Kabbânî, Kahire'de Ozbekiyye Bahçeleri yakınlarındaki Politeama tiyatrosunu kiraladı ve bütün oyunlarını burada oynayarak Hamzatu'lMuhtâl adlı komediyi repertuvarına ekledi. Ayrıca Selîm en-Nakkâş̧'ın çevirdiği Aida operası ve Racine' in eseri Mithritade' 1 Lubâbu'l-Ğarâm ev Mitridât adıyla oynanmıştır. Grup, Mısır halkı arasında çok popüler oldu ve mükemmel oyunculuk ve müzikalleriyle büyük beğeni topladı (Sadgrove, 2010, 268269). Neredeyse bütün gösterimlerinin ortalarında veya sonlarında, seyircilerin ilgisini daha da çok çeken şarkılara da yer verilmekteydi. Şarkının seyirci üzerindeki müthiş etkisi nedeniyle bu dönemdeki tiyatro gruplarında güzel sesli şarkıcılar, diğer sanatkârlardan daha önemliydi (Er, 1990, s.139). el-Kabbânî, Mısır Hidivi Tevfîk' in grubun Aralık 1884' de Kahire Opera Binası'nda sunulan ünlü Fatımi Halifesi hakkında bir oyun olan el-Hâkim Biemrillah adlı müzikal performansından çok etkilendiği söylenir (el-Cundî, 1954, s.250). elKabbânî, 1885 yılının başlarında İskenderiye'ye gelir, sonrasında ise 'Âkibetu's-Siyâneti ve'l-Ğâ'iletu'l-Hiyâneti ve el-İntikâm adlı iki yeni oyununu sergilemek için Kahire'ye döner (Haffâr, 2006, s.207).

Halîl ve Abdulhamid adlı oğullarını ve dört kızını Şam'da bırakan el-Kabbânî, on yıldır hasret kaldığı ailesini görmek için Şam’a giderek tiyatroyu bırakmıştır. Ailesiyle birlikte kendisini evine davet eden dostu Suleymân elCundî̀ye Humus'ta misafir olmuştur. Bir yıl burada kalmıştır ve çocuklarının iş sahibi olması için onlara bir nişasta fabrikası tesis etmiştir. İki sene burada kaldıktan sonra Şam'a dönerler. 1891 yılında el-Kabbânî tek başına Mısır'a döner ve burada mesleğinin zirvesine ulaşır. Buradaki tiyatrosu yakılınca da İstanbul'a gitmiş ve orada Bâbıâli kâtiplerinin reisi Ahmed İzzeddîn el-Abid Paşa'nın misafiri olmuştur. Burada bir yıl kalmış ve Sultan'a Türkçe, Arapça ve Farsça muvaşşahalar söylemiştir. el-Kabbânî Sultan'ın iyiğine mazhar oluşunun ardından Mısır'a dönmüştür (el-Cundî, 1954, s.251; Savran, 1991, s.66).

1884-1900 yılları arasında Misır ile Suriye arasında gidip gelen el-Kabbânî'nin ekibinde önde gelen şairler, yönetmenler, yazarlar ve şarkıcılar yer almıştır. Bu süre zarfında Mısır'da büyük izler bırakan el-Kabbânî; Seyyîd Dervîş, Kâmil el-Hal'î ve Selâme el-Hicâzî gibi önemli isimleri yetiştirmiş ve Suriye kültürel yaşamını âdeta Mısır'a taşımıştır. Oyunlarında topluma daima bir mesaj vermeye gayret eden el-Kabbânî'yi Mısırlılar kendilerinden biri görerek sevmişlerdir (İshakoğlu, 2010, s.194). 
Aralık 1885'de Mısır basınında çıkan bir haber, el-Kabbânî'nin Ozbekiyye Bahçeleri'nde sergilediği performansların halkın ahlakını bozduğundan şikâyet ediyordu. Bıyıklarını ve sakallarını tıraş eden erkek oyuncuların kadın rollerini üstlendikleri ve pek de ahlaki olmayan davranışlar sergiledikleri anlatılmaktaydı. Ancak bu duruma yapılan yorumların neticesinde meydana gelebilecek sonuçlardan korkan Vali, onları yasakladığında ve oyunculara kadın olarak göründükleri için güçlü bir kınama yayımladığında ilgili oyuncular Suriye'den çoktan kovulmuştu. Gazete, bu erkek oyuncuların Mısır'da bu şekilde oynamalarını önlemek için gerekli önlemlerin alınacağından emindi. 1884'te Suriye'deki bir okulda bazı öğrenciler, onları taklit etmeye karar vermiş ve Suriye hükümeti okul müdürünü cezalandırmak zorunda kalmıştı (Sadgrove, 2010, s.269-270).

el-Kabbânî, kendisini Mısır'da takip edip beğenen Amerikalı zenginlerin davetine binaen kumpanyasından yirmi oyuncuyla birlikte 1892 yılında Amerika'ya gitmiş Chicago şehrinde altı ay süreyle kalarak oyunlarını sergilemiş ve büyük bir teveccühle karşılaşmıştır (İshakoğlu, 2010, s.195; Savran, 1991, s.66). Mısır'da on yedi yıl gibi uzun bir süre kalmasının ardından 1900 yılında Suriye'ye dönmüştür. Ancak Şam'a dönüşünde ise aslında eskisi gibi oyunlara çıkamamış ve özel gecelerde sunuculuk yapmıştır.

$\mathrm{Bu}$ dönemde çeşitli nedenlerle Kahire'ye gidip gelen edebiyatçllar ve tiyatrocular sayesinde Kahire, Arap dünyasında tiyatro sanatının merkezi konumuna gelmiştir. Bu sayede de müzikal drama Arap edebiyatında bir edebi tür durumuna gelmiştir. Bu arada Hristiyanların yanı sıra Müslümanlar da tiyatro sanatında yeteneklerini sergileyebilmişlerdir. Örneğin Suriye'de İbrâhîm el-Ahdeb (1826-1891) Makidonyalı İskender ve Endülüslü İbn Zeydûn adlı oyunlarıyla Arap edebiyatına oldukça mühim katkılarda bulunmuştur. İbrâhîm el-Ahdeb, bazıları orijinal olsun bazıları da Avrupa oyunlarından uyarlama olsun toplamda yirmi kadar oyun kaleme almıştır. Orijinal oyunlarına bakıldığında ise İslami temaların hâkim olduğu göze çarpar. Bu oyunlardan birisi ise et-Tuhfetu'r-Reşîdiyye fî Ulûmi'l-Arabiyye adını taşır ve didaktik özelliklere haizdir (Haffâr, 2006, s.207; Savran, 1991, s.67).

Suriyeli oyun yazarı ve oyuncu Ahmed Ebû Halîl el-Kabbânî, Arap operetinin yaratıcısı ve melodramın babasıydı. Müzikaller, komediler ve tek perdelik fars dâhil olmak üzere yaklaşık yüz parça yazdı veya uyarladı. Sergilediği oyunların çoğu diğer Arap yazarlar tarafından yazılmış veya Corneille, Racine, Voltaire ve Victor Hugo'nun eserleri de dâhil olmak üzere Avrupa 
klasiklerinden uyarlanmıştır. Binbir Gece' deki Hârûn er-Reşîd'in hikâyelerinden ve benzeri diğer masallardan yararlanarak Arap halkını ve tarihi mirasını dramatik bir ilham kaynağı olarak kullanma geleneğinin yaratılmasına yardımcı oldu. Kostümleri kendisi tasarladı, şarkılar söyleyip danslar etti (Sadgrove, 1998, s.625).

el-Kabbânî tiyatrosunun kapatılması için çeşitli nedenler öne sürülmüştür. Görünüşe göre, kadınların ulemaya kocalarının asla evde olmadığı için şikâyette bulunmaları o kadar davetkârdı ki ayrıca işverenler işlerinin ihmal edildiğini de iddia ettiler. Hikâyenin bir versiyonuna göre ulema, dönemin valilerinden tiyatroyu kapatmaların talep etti. Başka bir versiyon ise bazı şeyhlerin bir komedi olan Mârûn en-Nakkâş'in Ebu'l-Hasen el-Muğaffal ev Hârûn er-Reşîd adlı oyununun hem Halîfe er-Reşîd' in makamını hem de şahsını karaladığını ileri sürmekteydi. Şeyh Sa'îd el-Ğabrâ', tiyatronun artan popülaritesinin bir sonucu olarak günahın Suriye'de yayıldığını ve kadınların erkeklerle kaynaştığını padişah Abdulhamîd'e şikâyet etti. 1884 yılında Şam' da oyunculuğu yasaklayan bir emir çıkarıldığı ve el-Kabbânî'nin tiyatrosunun belki bir kundaklama saldırısı sonucu yerle bir edildiği iddia edildi (Sadgrove, 2010, s.268). Buna rağmen yoluna devam eden el-Kabbânî́nin oyunculuğu seyirci tarafından takdir edilmeye devam etti. Gösterilerin sonunda veya arasında dönemin en popüler şarkıcısı 'Abduh elHamuvlî şarkı söylerdi. el-Kabbânî Suriye’ye döndüğünde İskender Farah grubun yöneticisi olarak görev yaptı. Böylece 1888 yılının ortasında Farah kumpanyadan ayrıldı ve diğer oyuncularla birlikte kendi grubunu kurdu. Büyük Mısırlı aktör / şarkıcı Selâme Hicâzî'nin önemli isimlerinden biri olduğu yeni topluluk, 1891-1904 yılları arasında olağanüstü popülerlik kazand1. Bu arada el-Kabbânî́nin topluluğu seyircilerini kaybediyordu ve bu yüzden el-Kabbânî Mısır'a döndüğünde daha geniş bir halkı çekmek için oyunlarına bazı yeni unsurlar ekledi. Şarkıcı Leylâ'nın gruptaki varlığından dolayı bu sefer daha başarılı oldular (Sadgrove, 2010, s.270).

el-Kabbânî'nin topluluğu Şubat 1889'da Opera Binası'nda bir kez daha sahne aldı ve Mayıs 1889'a kadar ed-Denûb'de bir mekânda ardından ise 1889'un sonuna kadar Tanta'da ve sonra Abdulazîz Caddesi'ndeki bir tiyatroda oynadıkları oyunlardan sonra topluluk Kahire'ye geri döndü. elKabbânî, repertuvara iki oyun daha ekledi: Selîm en-Nakkâş'ın Corneill'in Les trois Horaces et les trois Curiaces uyarlaması olan Mâyû ve Hûrâs, Alba ve Roma arasındaki savaş zamanında geçen bir aşk hikâyesini ele alır ve bir 
diğer oyun ise el-Kabbânî'nin Hârûn er-Reşîd ma'a'l-Emîr Ğânim b. Eyyûb ve Kutu'l-Kulûb adını taşır (Sadgrove, 2010, s.270).

el-Kabbânî, 1897 yılına değin başta Kahire ve İskenderiye olmak üzere Mısır'ın muhtelif illerinde ve birkaç kez de Şam'da temsiller vermiştir. Kendi özel tiyatrosuna ise ancak 1896 yılı sonlarında sahip olmuştur. Zamanın Maarif Bakanlığı müfettişlerinden 'Abdurrâzık 'Inâyet' in kendi parasıyla yaptırdığı ve Kahire'de yer alan bugünkü el-'Atebe meydanı civarında tahsis ettiği bu tiyatro, Ocak 1897' de el-Kabbânî'nin temsillerine yer verir (el-Cundî, 1954, 250; Er, 1990,139). Grubunda artık Ahmed Ebu'l-Adl, Suriyeli yönetmen Suleymân el-Kardâhî, Suriyeli şarkıcı Suleymân el-Bûstânî ve 'Abduh elHamuvlî̀ nin oyunlar arasında şarkı söyleyen kardeşleri Meryem, Hilanah ve Haninah Sammat gibi başrol oyuncuları bulunmaktaydı. Grubun devam eden başarısı, her performansını şarkılarıyla bitiren ünlü Halepli genç şarkıcı Melîke Surûr'un varlığından da kaynaklanıyordu. Birkaç yıldan beri kendi grubuna sahip olan Suriyeli aktör Suleymân el-Haddâd da bir süre el-Kabbânî ile çalıştı (Sadgrove, 2010, s.271).

el-Kabbânî topluluğu tarafından sergilenen 150 gösteriden $45^{\prime}$ inin yabanc1 kökenli oyunlar, 28 'inin XIX. yüzyıldan kalma eserler ve 17'sinin de trajedi olduğu tahmin edilmektedir. Bazıları Avrupa eserlerinin çevirilerinin uyarlamalarl, diğerleri ise orijinal eserleri olmak üzere sadece sekiz oyunu yayımlandı. Diğerleri ya kayboldu ya da el yazması halinde kaldı (Sadgrove, 2010, s.272).

el-Kabbânî, oyunlarını oldukça retorik klasik bir Arapça ile kaleme aldı. Ancak nazmettiği şiirleri, 1920'lerde Ahmed Şevkî'nin oyunlarında bulunacak nitelikte değildi. el-Kabbânî, İslam öncesi Emevi ve Abbasi dönemlerinin ünlü klasik şiirlerinden satırları, hadislerle ve Kur'an'dan ayetlerle birleştirdiği bir şiir yazma yeteneğine sahipti. Halkın beğenisine cevap veren oyunlar, kendi bestelediği melodilerle bir dizi şarkı ve müzik arasına, Endülüs muvaşşahalarının koro halinde söylenmesine fursat vermekteydi. Başroller şarkıcılar tarafından icra edilecek şekilde yazılmıştı. Selâme Hicâzi gibi dönemin önde gelen şarkıcıları tarafından icra edildiğinde izleyicileri arasında çok popülerdi (Sadgrove, 2010, s.272).

el-Kabbânî, çoğu dört veya beş perdelik oyunlarını müzikal, edebi, dramatik, tarihi, romantik, ahlaki ve savaşçı olarak tanımlar. Ahlaki dersleri vaaz etmenin bir yolu olarak dramatik türü kullanarak adaleti ve ahlakı korumaya çalışır (Sadgrove, 2010, s.272). 
Aynı döneme ait ara ara şiirlerinde olduğu gibi el-Kabbânî, performanslarına genellikle Mısır Hidivi Abbâs'ı öven bir koro halinde zafer ilahileri söyleyerek veya Osmanlı halifesi ve padişahı Abdülhamid'e övgü veya dualarla başlar ve bitirir. Bir oyunun sonsözünde Hârûn er-Reşîd' in adaletini övdüğünde Abdülhamid'in adaletiyle karşılaştırır. Çok yetenekli bir isim olan el-Kabbânî Arap tarihi, edebiyatı ve efsanesinden esinlenen ve beslenen Arap ulusal tiyatrosunun kuruluşunda önemli bir figürdü (Sadgrove, 2010, s.273).

el-Kabbânî, Misır ve Suriye'de tiyatro geleneğinin temellerini atan en önemli isimlerden birisiydi. Melodramın babası olarak nitelendirilip müzikal drama veya operetin popülerleşmesine yardımcı oldu. Kendisi müzik tiyatrosunun ustası olup aynı zamanda birçok tanınmış Arap müzisyeni yetiştirdi. Müritleri arasında Mısırlı müzisyen ve besteci Muhammed Kâmil el-Hula'i ve aktör, besteci, şair ve yazar Dâvud Kustantin Hûrî vardı. el-Kabbânî, 1870'lerden 1900'lerin başlarına kadar faaliyetleri Mısır'daki tiyatronun sağlam kuruluşu, refahı ve popülaritesi için temel teşkil eden Lübnanlı / Suriyeli oyun yazarları ve oyuncu-yöneticiler grubunun önde gelen bir üyesiydi (Sadgrove, 2010, s.273).

\section{Eserleri}

Muhammed Yûsuf Necm'e göre el-Kabbânî'nin sahnelediği oyun sayısı otuz birdir. Bunlardan on beşi kendi eseri iken, geri kalanı ise ya Mârûn elNakkâş'dan Necîb Haddâd'a kadar uzanan diğer Arap yazarlar tarafından yazılmış ya da başta Corneille, Racine, Victor Hugo ve Alexandre Dumas olmak üzere Avrupalı oyun yazarlarının oyunlarından serbestçe çevrilmişti (https://shodhganga.inflibnet.ac.in/bitstream/10603/104470/10/10 chapter\%202.pdf 05.10.2020.)

el-Kabbânî́nin toplamda altmıştan fazla tiyatro eserine sahip olduğu bilinirken bazıları şu şekildedir:

1. Unsu'l-Celîs

2. el-Emîr Mahmûd ve Zehru'r-Riyâd

3. el-Emîr Mahmûd Neclu Şâhî'l-Acem

4. 'Âkibetu's-Siyâne ve Ğâiletu'l-Hiyâne

5. Ğanim İbn Eyyûb

6. Mecnûnu Leylâ 
7. Cemîl ve Cemîle

8. 'Afife ve'l-Emîr Ali

9. Antara b. Şeddâd

10. eş-Şeyh Vaddah ve Misbâh ve Kûtuh-Ervâh

11. Nâkiru'l-Cemîl

12. Kisrâ Enû Şîrevân

13. el-Kevkebân

14. 'Afife,

15. Hârûn er-Reşî̀ ma'a'l-Emîr Ğânim b. Eyŷ̂b ve Kutu'l-Kulûb

16. Hârûn er-Reşî̀ ma'a Unsi-l-Celîs (Savran, 1991, s.67),

\section{Sonuç}

Suriye'de tiyatro sanatının tesis edilmesinde çok önemli bir yeri olan el-Kabbânî, aynı zamanda Mârûn en-Nakkâş, George Ebyad, Suleyman el-Kardâhî ve Ya'kûb Şannû' gibi genel olarak Arap tiyatrosuna çok önemli katkılar sağlayan isimler arasındadır. el-Kabbânî sadece Suriye değil aynı zamanda o dönem içerisinde tiyatrocuların akın ettiği Mısır'da da sergilediği ve kaleme aldığı oyunlarla oldukça ön plana çıkan bir isim olmuştur. el-Kabbânî'nin Arap tiyatrosuna sağladığı en önemli katkı, teliflerinde seçtiği konu ve kullandığ1 dil olmuştur. Kendisi senaristlerin dikkatlerini Arap tarihine ve mirasına çekmiş ve bu alanda örnek olacak pek çok eser meydana getirmiştir. Dil bakımından oyunlarında fushâya önem vermiş ve senaryo yazımında şiire ehemmiyet göstermiş̧ir. Aşk temalarının hâkimiyeti, olayların romantizme benzer olan niteliği, şarkı söyleme tutkusu ve oyunlarda ahlaki önemi açıkça belirtme arzusu Suriyeli aktör ve oyun yazarının çalışmalarına katkıda bulunan diğer faktörler arasındadır. Tiyatrocu el-Kabbânî, Suriye'de sergilediği oyunlar dolayısıyla toplumun kimi kesimlerinde tepki görmüştür. Akabinde tutkunu olduğu bu sanattan vazgeçmemiş ve Misır'da oyunlarına devam etmiştir. Bu esnada daha da ilerleme kat etmiş ve adını yurt dışında duyurabilmiştir. Mısır'daki tiyatrosunun yakılması üzerine memleketine geri dönen el-Kabbânî́yi tiyatrodan uzak olarak devam ettiği yaşamında mutsuz bir insan haline gelmiştir. Henüz küçük yaşlardan beri bu sanata ilgisi olan ve dönemin en yetenekli isimleri arasında olan el-Kabbânî, yaşadığı dönemde Arap tiyatrosuna sağladığı katkıların ve etkisinin çok kıymetli olduğunu ifade etmek gerekir. 


\section{EXTENDED ABSTRACT}

\section{Ahmad Abû Halîl Al-Qabbânî in the Modern Syrian Theater

\author{
* \\ Turgay Gökgöz \\ Kilis 7 Aralık University
}

The birth of the modern Arab theater took place in 1848 in Syria, which was within the Ottoman territory. However, as the best writers and actors are in search of better conditions, the art of theater seems to be concentrated in Egypt. Since music has an important place in theaters, the most valuable musicians were working there. While amateur actors move freely from one community to another, actresses have begun to appear on the stage. However, the actresses were mostly Jewish and Christian women. It is also seen that Muslim women from some powerful families appeared on the stage for the emancipation of women until World War I.

With the occupation of Egypt in 1798 by Napoleon, developments in modern literature took place, and progress was made in various fields, especially in literary and cultural activities. Although the first modern Arab theater started in Syria, it was concentrated in Egypt due to the good conditions and opportunities and the most valuable musicians in Egypt. In the 19th century, Egyptian theater companies began to travel to other Arab countries. In this context, it can be said that theater art started to develop first in Egypt, then in Lebanon and other Arab countries. In addition to these developments, Mârûn Nakkash came to the fore in the theater field in Lebanon, and staged her first theater play in 1847. In Syria, first theater play occured with the adaptation of the novel called Macedonian Alexander which was written by Lebanese Ibrâhîm al-Ahdeb and it was staged with the proposal of Governor Rashid Pasha. Besides, the most important name in the field of theater in Syria is Ahmad Abû Khalîl al-Qabbânî.

Ahmad Abû Khalîl al-Qabbânî (1833-1903) is considered to be one of the most prominent figures of theater in Syria. XIX. Ahmad Abû Khalîl al-Qabbânî, who is one of the pioneers of the 21st century Arab theater art and who has made great contributions to the development, compilation and representation of the art of theater, as well as its becoming musical, is a member of a Turkish 
family that migrated from Konya to Damascus He was born in 1833 in Damascus. al-Qabbânî's start of theater takes place towards the end of the 1860s. His transition from weighbridge to this art is due to his interest in music and song and his talent in this field. As it is known, the first Arab theater that started in Lebanon, a place close to Syria, was mostly in operetta. al-Qabbânî's also heard of Nakkash's plays of this kind and he was thrown into this field by watching the Lebanese performances in Damascus.

al-Qabbânî went to America in 1892 with twenty players from his troupe, based on the invitation of the American rich who followed and liked him in Egypt, stayed in Chicago for six months and exhibited his plays and met with great favor. He returned to Syria in 1900 after a long stay in Egypt for seventeen years. However, on his return to Damascus, he could not actually play as before and hosted special nights. al-Qabbânî, who has a very important place in the establishment of theater art in Syria, is also among the names who contributed very much to Arab theater in general, such as, Mârûn Nakkash George Abyad, Sulayman al-Kardâhî and Ya'qûb Sannû'. al-Qabbânî was a name that came to the fore with the plays he performed and wrote not only in Syria but also in Egypt, where theater actors flocked to that period. The most important contribution of al-Qabbânî to Arab theater was the subject he chose and the language he used in his works. He drew the attention of screenwriters to Arab history and heritage and created many works that set an example in this field.

In terms of language, he gave importance to fushâ in his plays and he gave importance to poetry in script writing. The dominance of love themes, the romantic nature of the events, the passion to sing, and the desire to clearly state the moral significance in plays are among the other factors contributing to the work of the Syrian actor and playwright. The theater player al-Qabbânî has been criticized by some segments of the society because of the plays he performed in Syria. Subsequently, he did not give up this art that he was passionate about and continued his plays in Egypt. In the meantime, it has made further progress and has been able to make its name heard abroad. Returning to his hometown after his theater in Egypt was burned down, al-Qabbânî became an unhappy person in his life away from the theater. al-Qabbânî, who has been interested in this art since his early ages and was one of the most talented names of the period, should be expressed that the contributions and influence he made to Arab theater during his lifetime were very valuable. 


\section{Kaynakça / References}

Amine, K. ve Carlson M., (2012). The theatres of Morocco, Algeria,Tunusia: Performance traditions of the Maghreb. London: Palgrave Macmillan.

Badawi, M. M., (1988) Early Arabic drama, Cambridge: Cambridge University Press.

el-Cundî, E. (1954). A'lâmu'l-Edeb ve'l-Fenn. I, Şam: Matba'atu Mecelleti Savti Sûriyye.

el-Fâhûrî, H. (1986) el-Câmi'u fì Tarîhi'l-Edebi'l-Arabî, Beyrut: âru'l-Cîl.

el-Haffâr, N. (2006) el-Mevsû́atu'l-'Arabiyye, C. XV, Şam.

Er, R. (1990). Modern Misır tiyatrosu. Ankara Üniversitesi Dil ve Tarih-Coğrafya Fakültesi Dergisi, 33(1-2), 123-140.

ez-Ziriklî, H. (1992), el-A'lâm Kâmûs Terâcim li'eşheri'r-Ricâl ve'n-Nisâ' mine'l'Arab ve'l-Musteşrikîn. I, Beyrut: Dâru'l-İlmi'l-Melayîn.

İshakoğlu, Ö. (2010) Osmanl Dönemi Suriye'sinde edebi ve külttürel faaliyetler: 18001918. Yayımlanmamış Doktora Tezi, İstanbul Üniversitesi Sosyal Bilimler Enstitüsü, İstanbul.

Osnes, B. (t.y). Acting an international Encyclopedia. California: ABC-CLIO

Sadgrove, P. (2010). Ahmad Abû Khalîl al-Qabbâni. Essays in Arabic Literary Biography 1850-1950, Wiesbaden: Harrassowitz Verlag.

Sadgrove, P. C. (1998) al-Qabbânî, Ahmad Abu Khalîl. Encylopedia of Arabic Literature, 2, London: Routledge.

Savran, A. (1991). 19. Yüzyll Osmanllar döneminde yeni Arap edebiyatı. Erzurum: Atatürk Üniversitesi Yay.

Ghaleb, A. M. A. (2011). Reconciliations a study of inter cultural negotiations in Tawfiq Al Hakims plays. 05.10.2020 tarihinde https://shodhganga.inflibnet.ac.in/bitstream/10603/104470/10/10 chapter\%202.pdf adresinden erişilmiştir.

\section{Kaynakça Bilgisi / Citation Information}

Gökgöz, T. (2020). Modern Suriye tiyatrosunda Ahmed Ebû Halîl elKabbânî. OPUS-Uluslararası Toplum Araştırmaları Dergisi, 16(Eğitim ve Toplum Özel Sayıs1), 6460-6477. DOI: 10.26466/opus.819011 